\title{
RISK FACTORS AND OUTCOME IN 100 PATIENTS WITH ANEURYSMAL SUBARACHNOID HEMORRHAGE
}

\author{
Leonardo Bonilha', Edilson L. Marques², Edmur F. Carellï, Yvens B. Fernandes², \\ Arquimedes C. Cardoso ${ }^{4}$, Marcos V.M. Maldaum', Guilherme Borges ${ }^{3}$
}

\begin{abstract}
Objective: Clinical and surgical outcome of patients with subarachnoid hemorrhage (SAH) due to ruptured aneurysm were assessed in comparison to pre-operative data and risk factors such as previous medical history, clinical presenting condition, CT findings and site of bleeding. Methods. We evaluated 100 consecutive patients with aneurysmal SAH. Gender, color, history of hypertension, smoking habit, site and size of aneurysm, admittance and before surgery Hunt Hess scale, need for cerebro-spinal fluid shunt, presence of complications during the surgical procedure, Glasgow Outcome Scale, presence of vasospasm and of rebleeding were assessed and these data matched to outcome. For statistical analysis, we applied the chisquared test or Fisher's test using the pondered kappa coeficient. Kruskal-Wallis test was used for comparison of continue variables. Tendency of proportion was analyzed through Cochran-Armitage test. Significance level adopted was $5 \%$. Results. Patients studied were mainly white, female, without previous history of hypertension and non-smokers. Upon hospital admittance, grade 2 of Hunt-Hess scale was most frequently observed (34\%), while grade 3 of Fisher scale was the most prevalent. Single aneurysms were most frequent at anterior circulation, between 12 and $24 \mathrm{~mm}$. The most frequent Glasgow Outcome Scale observed was 5 (60\%). Hunt Hess upon the moment of surgery and presence of complications during surgical procedure showed positive correlation with clinical outcome $(p=0.00002$ and $p=0.001$, respectively). Other variables were not significantly correlated to prognosis. Tendency of proportion was observed between Hunt-Hess scale and Fisher scale. Conclusion: Among variables such as epidemiological data, previous medical history and presenting conditions of patients with ruptured aneurysms, the Hunt-Hess scale upon the moment of surgery and the presence of surgical adversities are statistically related to degree of disability.
\end{abstract}

KEY WORDS: brain aneurysm, subarachnoid hemorrhage, outcome.

Fatores de risco e prognóstico em 100 pacientes com hemorragia subaracnóidea por rutura de aneurisma

RESUMO - Objetivo: Resultado do tratamento de pacientes com hemorragia subaracnóidea (HSA) decorrente de ruptura aneurismática foi avaliado e comparado a variáveis pré-operatórias como história médica pregressa, condição clínica da HSA, achados à tomografia computadorizada (TC) e local de sangramento. Método: Avaliamos 100 pacientes consecutivos com HSA por ruptura de aneurisma. Variáveis avaliadas foram gênero, cor, história de hipertensão arterial sistêmica e tabagismo, tamanho e local de aneurisma, pontuação à escala de Hunt-Hess à admissão e no momento antes da cirurgia, necessidade de derivação liquórica, presença de complicações durante a cirurgia, escala de resultado de Glasgow (GOS), presença de vasoespasmo e ressangramento. Dados obtidos foram comparados estatisticamente com resultado do tratamento. Testes de qui-quadrado ou Fisher foram aplicados usando coeficiente ponderado kappa. Teste de Kruskal-Wallis foi utilizado para comparação de variáveis contínuas. Tendência de proporção foi analisada através do teste de Cochran-Armitage. 0 nível de significância adotado foi 5\%. Resultados: Os pacientes estudados foram predominantemente mulheres brancas sem história de hipertensão ou tabagismo. À admissão hospitalar, grau 2 na escala de Hunt-Hess foi mais frequente (34\%), enquanto grau 3 na escala de Fisher foi mais prevalente. Aneurismas mais frequentes foram únicos na circulação anterior, entre 12 e $24 \mathrm{~mm}$. A pontuação na escala de GOS mais frequente foi $5(60 \%)$. Pontuação na escala de Hunt-Hess avaliada no momento da cirurgia e presença de complicações cirúrgicas tiveram correlação positiva com resultado de tratamento $(p=0,00002$ e $p=0,001$, respectivamente). As demais variáveis não se mostraram correlacionadas com prognóstico. Tendência de proporção foi observada entre as escalas de Hunt-Hess e Fisher. Conclusão: Dentre 1-variáveis epidemiológicas, 2-história médica pregressa e 3-condições clínicas da HSA, a pontuação na escala de HuntHess no momento da cirurgia e a presença de complicações cirúrgicas são estatisticamente correlacionadas com resultado de tratamento.

PALAVRAS-CHAVE: aneurisma cerebral, hemorragia subaracnóidea, evolução.

Division of Neurosurgery, Department of Neurology, Faculty of Medical Sciences, State University of Campinas (UNICAMP), Campinas SP, Brazil: 'Medical Resident of Neurosurgery; ${ }^{2}$ Neurosurgeon; ${ }^{3}$ Associate Professor of Neurosurgery; ${ }^{4}$ Neuroscience post-graduation student.

Received 8 March 2001, received in final form 8 June 2001. Accepted 15 June 2001. 
The estimated prevalence of clinically relevant intracranial aneurysms ranges between 0.5 and $1 \%^{1-4}$. The incidence of serious cerebrovascular conditions has substantially decreased in the last 3 decades $^{5}$. The incidence of aneurysmal subarachnoid hemorrhage (SAH), however, has not changed and remains approximately 1 per 10000 people annually,7. SAH due to the rupture of an intracranial aneurysm is a potentially fatal event. Among those who suffer an $\mathrm{SAH}, 12$ percent may die before reaching medical attention and 40 percent die within the first month after the bleeding ${ }^{8}$. Many patients who survive SAH continue to experience social and environmental adaptation problems and significant reduction in quality of life assessment scales ${ }^{9}$. Risk factors for SAH include heritable connective tissue disorders, familial history and environmental factors ${ }^{10,11}$.

General outcome of patients victims of aneurysmal SAH has been extensively debated in the past few years accordingly to risk factors, presenting condition, findings upon image investigation, clinical evolution and treatment complications ${ }^{12}$.

In this article, we have decided to prospectively study the outcome of 100 patients with aneurysmal SAH in order to evaluate the supposed relation between the degree of disability to risk factors, clinical and surgical conditions.

\section{METHOD}

We have prospectively studied 100 consecutive nonselected patients admitted in the period comprised between March 1996 and April 1999 for medical assistance due to ruptured intracranial aneurysm. Only those patients who were submitted to surgical treatment and underwent clipage of one or more aneurysms were eligible for the study. History for risk factors such as age, gender, history of hypertension or smoking habit were obtained with the patient or close relatives. The clinical presenting condition information included the Glasgow Coma Scale ${ }^{13}$ and the Hunt-Hess scale ${ }^{14}$. Radiological data were analyzed through computed tomography scans (CT) and the Fisher scale ${ }^{15}$.

All patients underwent 4-vessel intracranial digital an- giography, from which data such as arterial location and size of aneurysm were obtained. The presence of radiological or clinical evidence for cerebral vasospasm and presence of acute hydrocephalus during hospitalization and need for transient or definite cerebral spinal fluid (CSF) drainage were analyzed. We also highlighted patients who experienced rebleeding and those who suffered hyponatremia in the hospitalization period. All patients underwent surgery for aneurysm clipage within the period necessary for their clinical status to be stable and when surgery could have then be performed without further risks of ischemia.

Surgical complications were registered whenever small perforating arteries were lesioned during the surgical procedure. Lesions of cranial nerves were not included upon surgical complications and were assessed in isolation. General outcome and degree of disability were defined according to the Glasgow Outcome Scale as rated in three to six month outpatient follow-up, except in cases of death ${ }^{16}$.

Analysis of the obtained information involved a descriptive assessment and comparison of variables with chisquared or Fisher's exact test. For evaluation and interpretation of concordance among Hunt-Hess and Fisher scales, the kappa pondered coefficient was used. Comparison of non-parametric variables involved the Kruskal-Wallis test, while tendency of proportion was assessed through the Cochran-Armitage test. Significance level adopted was $5 \%$.

\section{RESULTS}

We observed that 72 patients were female. Mean age was 45 years with a standard deviation of 13 years. Seventy-eight percent were white, $17 \%$ nonwhite and $5 \%$ black. A slight majority of patients had a previous history of essential hypertension (58\%), while most of them (94\%) had no history of smoking. Upon hospital admission, bleeding event and moment of surgery, patients were ranked according to the Hunt-Hess scale (Table 1).

$\mathrm{CT}$ findings were analyzed according to the Fisher scale assessed upon hospital admission (Table 2).

Anteriorly located aneurysms were most prevalent $(73 \%)$, followed by multiple $(23 \%)$ and posteriorly located $(4 \%)$. Anatomical site of the intracerebral aneurysm was observed according to Table 3.

Table 1. Clinical condition according to the Hunt-Hess scale evaluated upon different moments of treatment.

\begin{tabular}{cccc}
\hline Hunt-Hess & Hospital admission & Bleeding event & Moment of surgery \\
\hline 1 & $33.00 \%$ & $24.00 \%$ & $72.00 \%$ \\
2 & $34.00 \%$ & $39.00 \%$ & $8.00 \%$ \\
3 & $25.00 \%$ & $31.00 \%$ & $12.00 \%$ \\
4 & $6.00 \%$ & $5.00 \%$ & $5.00 \%$ \\
5 & $2.00 \%$ & $1.00 \%$ & $2.00 \%$ \\
\hline
\end{tabular}


Table 2. Computed tomography findings according to the Fisher scale assessed upon Hospital admission.

\begin{tabular}{cc}
\hline Fisher & Frequency \\
\hline 1 & $24 \%$ \\
2 & $26 \%$ \\
3 & $33 \%$ \\
4 & $17 \%$ \\
\hline
\end{tabular}

Table 3. Anatomical site of the intracerebral aneurysms.

\begin{tabular}{lc}
\hline Site of aneurysm & Frequency \\
\hline Multiple & $23.00 \%$ \\
Posterior communicating artery & $19.00 \%$ \\
Middle cerebral artery & $18.00 \%$ \\
Anterior communicating artery & $15.00 \%$ \\
Internal carotid artery & $14.00 \%$ \\
Anterior cerebral artery & $5.00 \%$ \\
Basilar artery & $3.00 \%$ \\
Pericallosal artery & $2.00 \%$ \\
Posterior cerebral artery & $1.00 \%$ \\
\hline
\end{tabular}

Table 4. General outcome assessed through the Glasgow Outcome Scale (GOS) evaluated upon hospital dischargement and within a three to six-month period of outpatient follow-up.

\begin{tabular}{cc}
\hline GOS & Frequency \\
\hline 1 & $17 \%$ \\
2 & $2 \%$ \\
3 & $9 \%$ \\
4 & $12 \%$ \\
5 & $60 \%$ \\
\hline
\end{tabular}

Forty-four percent of the aneurysms had a diameter smaller than $12 \mathrm{~mm}, 46 \%$ between $12 \mathrm{~mm}$ and $24 \mathrm{~mm}$ and $10 \%$ had more than $24 \mathrm{~mm}$.

Six percent of the group of patients studied presented complications after the angiographic procedure, while $28 \%$ presented adversities during the surgical procedure. Nine percent were submitted to external cerebro spinal fluid shunt, and $5 \%$ remained shunt dependent. Among pre-surgical complications, clinical or radiological vasospasm was observed in 3 patients, rebleeding in $6 \%$ and hyponatremia in $7 \%$.
Post-surgical complications involved metabolic or infection derangement observed in 15 patients. Also, intra operative damage to cranial nerves was present in 13 patients, 8 of them involving the facial nerve, 6 the oculomotor nerve, 1 involving both the oculomotor and the abducent nerves and in another patient both the oculomotor and the facial nerves.

General outcome was assessed through the Glasgow Outcome Scale (GOS) evaluated upon hospital discharge and within a three to six-month period of outpatient follow-up (Table 4).

The elevated number of patients with GOS $=1$ $(17 \%)$ is explained by the fact that the hospital where the study was conducted is an educational institution for medical training and its medical staff is formed by a large number of in-training doctors.

Statistical analysis showed no significant correlation between demographic features such as age, gender, history of hypertension, smoking habits and age. Also, these data were not statistically related HuntHess and Fisher scale or to size and location of aneurysm. Hunt-Hess and Fisher scales were not correlated as well, albeit trend of progression between these two scales was observed (Cochran-Armitage test $\mathrm{p}<0.001)$. None of clinical complications mentioned above, such as hydrocephalus, CSF shunt, hyponatremia, vasospasm, metabolic or infective adversities was related to outcome. Neither were related the size or location of aneurysm to outcome. The presence of cranial nerve lesions was not related to the Hunt-Hess scale, Fisher scale or GOS.

Intra-operative complications (lesions of perforating arteries) were statistically related to outcome $(p<0,001)$. Hunt-Hess upon surgical procedure was also significantly correlated to level of disability $(p=0,0002)$. The Fisher scale, despite progressing with tendency of proportion with the Hunt-Hess scale, did not reach, as the Hunt-Hess scale, statistically significant relation to outcome $(p=0.082)$.

\section{DISCUSSION}

The precise pathological mechanism responsible for development of intracranial aneurysms is still matter of debate. The smaller quantity of connective tissue surrounding cerebral vessels ${ }^{17}$, the attenuated tunica media and lack of external elastic lamina of intracranial arteries may be key ethiological features. Arterial hypertension coexists in high percentage of patients ${ }^{6,18-25}$ and it has been proposed as an etiological factor, even though the exact relationship is not completely defined ${ }^{26}$. Cigarette smoking 
is the single acquired factor that has been proved to confer risk for aneurysmal subarachnoid hemorrhage ( 3 to 10 times higher among smokers) ${ }^{18-23}$. Congenital predisposition for intracranial aneurysm is supported by considerable evidence, particularly concerning inherited connective tissue disorders and familial predisposition. Aneurysmal subarachnoid hemorrhage may therefore result from the addition of environmental factors and inherited predisposition.

Due to the serious consequences of the rupture of an intracranial aneurysm, we have decided to prospectively investigate the prognosis of a non-selected sample of 100 patients with subarachnoid hemorrhage and evaluate any attributable relation of degree of disability to risk factors, epidemiological features, clinical and radiological characteristics.

The overall incidence of SAH is higher among women $^{6,18,27}$. We observed $72 \%$ cases of female patients. Color of skin is a not condition associated with aneurysms; in the group studied the majority of patients was white (78\%). History of hypertension tends to coexist in a high percentage of patients. In our series, it was present in $58 \%$ of patients.

Saccular aneurysms are most commonly found in anterior circulation, while multiple aneurysms may contribute to up to one third of all cases. We found the posterior communicating artery to be the single most common site of aneurysm, followed by middle cerebral artery, anterior communicating artery and internal carotid artery. There was not statistically significant correlation between the site of aneurysm and level of disability (GOS). Also, there was not correlation of the size of the aneurysm and outcome, as well.

The Fisher scale also failed to depict significant correlation to outcome. We observed that the clinical condition (Hunt-Hess scale) assessed upon the moment of surgery showed significant correlation with outcome (GOS), while the presence of intra operative adversities was also statistically related to outcome. In summary, the level of disability as measured by GOS, was not statiscally correlated in a significant degree to history of hypertension, age, gender, arterial location of aneurysm and its size, hydrocephalus, rebleeding and vasospasm. There was not significant statistic correlation among these variables, as well. When tendency of proportion between the aforementioned data was assessed through the Cochran-Armitage test, there was trend of progression between Fisher and $\mathrm{HH}$, exclusively.
The main causes of poor outcome in patients with SAH are effects of the extent of bleeding ${ }^{28,29}$. The amount of blood leakage is clinically presumed by $\mathrm{HH}$ scale and directly through visual analysis of CT scan and Fisher scale rating. Progress in surgical techniques, early surgical approach and clinical advances have consistently decreased morbidity and mortality ${ }^{30}$, but the outcome still remains directly dependent upon the volume of the bleeding, and therefore clinical and radiological conditions ${ }^{31}$. Other factors such as delayed cerebral ischemia, hydrocephalus and rebleeding have been correlated to degree of disability ${ }^{29}$.

Clinical assessment scales such as Glasgow Coma Scale (GCS), World Federation of Neurosurgical Societies grading system (WFNS) and Hunt-Hess are proposed as good predictors of outcome in patients with SAH, though accurate prediction of disability remains quite imprecise, in part due to the moment of application of the scale used as predictor. A multivariate analysis comparing different scales applied during different clinical moments has suggested the best predictor to be the WFNS at clinical worst before treatment. $\mathrm{HH}$ scale was solely correlated to outcome when assessed at clinical worst ${ }^{12}$.

In our series, the WFNS and GCS were not assessed. However, we evaluated a large number of patients and the $\mathrm{HH}$ scale upon moment of surgery was related to outcome. Certainly, other clinical variables such as WFNS and GCS need to be analyzed in similar groups for comparison, but the fact that an easily performed scale $(\mathrm{HH})$ measured in a specific pre-operative time accurately predicts outcome is of some clinical relevance and must therefore be strongly considered.

We have also observed that the presence of unintended damage to perforating arteries during the microsurgical dissection of the Sylvian fissure contributes to a greater degree of disability. This could be attributed to technical difficulties of microdissection of the sylvian fissure or to an adverse aneurysm location. Microscopic dissection difficulties have been related by multiple logistic regression to thick arachnoid membrane and severe adherence between the frontal and the temporal operculae and, albeit increasing the surgical time, these factors are not directly related to any clinical consequence ${ }^{32-36}$. By consequence, the most important anatomical factor to predict an adverse outcome is an unfavorable location of the intracranial aneurysm and this should guide the pre-operative planning. 


\section{REFERENCES}

1. McCormick WF, Nofzinger JD. Saccular intracranial aneurysms: an autopsy study. J Neurosurg 1965;22:155-159.

2. Inagawa T, Hirano A.Ruptured intracranial aneurysms: an autopsy study of 133 patients. Surg Neurol 1990;33:117-123.

3. Winn HR, Taylor J, Kaiser DL. Prevalence of asymptomatic incidental aneurysms: review of 4,568 arteriograms. Stroke 1983;14:121.

4. Atkinson JL, Sundt TM Jr, Houser OW, Whisnant JP. Angiographic frequency of anterior circulation intracranial aneurysms. J Neurosurg 1989;70:551-555

5. Broderick JP, Phillips SJ, Whisnant JP, O'Fallon WM, Bergstralh EJ. Incidence rates of stroke in the eighties: the end of the decline in stroke? Stroke 1989;20:577-582.

6. Phillips LH 2d, Whisnant JP, O'Fallon WM, Sundt TM Jr.The unchanging pattern of subarachnoid hemorrhage in a community. Neurology 1980;30:1034-1040.

7. Ingall TJ, Whisnant JP, Wiebers DO, O'Fallon WM. Has there been a decline in subarachnoid hemorrhage mortality? Stroke 1989;20:718-724.

8. Schievink WI. Intracranial aneurysms. N Engl J Med 1997;336:28-40.

9. Hackett ML, Anderson CS. Health outcomes 1 year after subarachnoid hemorrhage: An international population-based study. The Australian Cooperative Research on Subarachnoid Hemorrhage Study Group. Neurology 2000;55:658-662.

10. Schievink WI, Michels VV, Piepgras DG. Neurovascular manifestations of heritable connective tissue disorders: a review. Stroke 1994;25:889-903.

11. Chambers WR, Harper BF Jr, Simpson JR. Familial incidence of congenital aneurysms of cerebral arteries: report of cases of ruptutrd aneurysms in father and son. JAMA 1954;155:358-359.

12. Chiang VL, Claus EB, Awad IA. Toward more rational prediction of outcome in patients with high-grade subarachnoid hemorrhage. Neurosurgery 2000;46:28-35.

13. Teasdale G, Jennett B. Assessement of coma and impaired consciousness. Lancet 1974;2:81-84.

14. Hunt WE, Hess RM. Surgical risk as related to time of intervention in the repair of intracranial aneurysms. J Neurosurg 1968;28:14-20.

15. Fisher CM, Kistler JP, Davis JM. Relation of cerebral vasospasm to subarachnoid hemorrhage visualized by computerized tomographic scanning. Neurosurgery 1980;6:1-9.

16. Jennett B, Bond M. Assessment of outcome after severe brain damage. Lancet $1975 ; 1: 480-484$.

17. Youmans JR (ed). Neurological surgery. 3.Ed. Philapelphia: W.B. Saunders, 1990.

18. Sacco RL, Wolf PA, Bharucha NE, et al. Subarachnoid and intracerebral hemorrhage: natural history, prognosis, and precursive factors in the Framingham Study. Neurology 1984;34:847-854.

19. Bonita R. Cigarette smoking, hypertension and the risk of subarachnoid hemorrhage: a population-based case-control study. Stroke 1986; 17:831-835.
20. Knekt P, Reunanen A, Aho K, et al. Risk factors for subarachnoid hemorrhage in a longitudinal population study. J Clin Epidemiol 1991; 44:933-939.

21. Longstreth WT Jr, Nelson LM, Koepsell TD, van Belle G. Cigarette smoking, alcohol use, and subarachnoid hemorrhage. Stroke 1992;23:1242-1249.

22. Juvela S, Hillbom M, Numminen H, Koskinen P. Cigarette smoking and alcohol consumption as risk factors for aneurysmal subarachnoid hemorrhage. Stroke 1993;24:639-646.

23. Adamson J, Humphries SE, Ostergaard JR, Voldby B, Richards P, Powell JT. Are cerebral aneurysms atherosclerotic? Stroke 1994;25:963-966.

24. Taylor CL, Yuan Z, Selman WR, Ratcheson RA, Rimm AA. Cerebral arterial aneurysm formation and rupture in 20,767 elderly patients: hypertension and other risk factors. J Neurosusrg 1995;83:812-819.

25. Toftdahl DB, Torp-Pedersen C, Engel UH. Strandgaard S, Jespersen B. Hypertension and left ventricular hypertrophy in patients with spontaneous subarachnoid hemorrhage. Neurosurgery 1995;37:235-239.

26. Inci S, Spetzler RF. Intracranial aneurysms and arterial hypertension: a review and hypothesis. Surg Neurol 2000;53:530-540.

27. Longstreth WT Jr, Nelson LM, Koepsell TD, van Belle G. Clinical course of spontaneous subarachnoid hemorrhage: a population-based study in King County, Washington. Neurology 1993;43:712-718.

28. Roos YB, de Haan RJ, Beenen LF, Groen RJ, Albrecht KW, Vermeulen M. Complications and outcome in patients with aneurysmal subarachnoid haemorrhage: a prospective hospital based cohort study in the Netherlands. J Neurol Neurosurg Psychiatry 2000;68:337-341.

29. Schutz H, Krack P, Buchinger B, et al. Outcome of patients with aneurysmal and presumed aneurysmal bleeding: a hospital study based on 100 consecutive cases in a neurological clinic. Neurosurg Rev 1993;16:15-25.

30. Hutter BO, Kreitschmann-Andermahr I, Mayfrank L, Rohde V, Spetzger U, Gilsbach JM. Functional outcome after aneurysmal subarachnoid hemorrhage. Acta Neurochir (Wien) 1999;72(Suppl):157-174.

31. Pahl F. Prognostic factors in subarachnoid hemorrhage of idiopathic or aneurysmal origin (Abstract). Thesis, São Paulo, 1995. Arq Neuropsiquiatr 1996;54:158.

32. Siqueira MG. Technical difficulties in the microsurgical dissection of sylvian fissure amd cistern: prospective identification of the responsible factors in 152 elective neurological surgeries. (abstract). Thesis, São Paulo, 2000. Arq Neuropsiquiatr 2000;58:1156.

33. Borges G, Gallani NR. Cerebral aneurysms. Assessment of 50 cases operated on and comparison with previous series. Arq Neuropsiquiatr 1997;55(2):287-91.

34. Dei-Anang K, Hey O, Borges G, Schurmann K, Muller W. Management of giant aneurysms. Arq Neuropsiquiatr 1990;48:231-235.

35. Hey O, Dei-Anang K, Borges G, Schurmann K, Muller W. Cerebral aneurysms: assessment of 377 cases (1956-1982). Arq Neuropsiquiatr 1990;48:225-230.

36. Borges G, Facure NO, Facure JJ. Clinical correlations of vascular spasms in the surgery of aneurysms. Zentralbl Neurochir 1987;48:219-221. 